\title{
Evaluation of Polycyclic Aromatic Hydrocarbon (PAH) concentrations in Crabs and Shrimps from Crude Oil Polluted Waters of Ogoniland in Rivers State, Nigeria.
}

\author{
${ }^{1}$ Mr. Kpobari Williams Nkpaa, ${ }^{2}$ Dr. Eka Bassey Essien, \\ ${ }^{3}$ Prof. Mathew Owhonda Wegwu \\ 1,2,3 (Department of Biochemistry, University of Port Harcourt, P.M.B 5323, Choba, Rivers State, Nigeria)
}

\begin{abstract}
This study was carried out to evaluate PAHs concentration in crabs (Callinectes pali)and shrimps (Penaeus notialis) collected from Kaa, B-Dere and Bodo City in Ogoniland, Rivers State, Nigeria. These samples were measured by gas chromatography with flame ionization detector (GC/FID). The Average concentrations of these PAHs ranged from below detection limit of 0.0001 to $90.7 \pm 1.00 \mu \mathrm{g} / \mathrm{kg}$ wet wt. in Callinectes paliand from 0.0001 to $77.5 \pm 1.65 \mu \mathrm{g} / \mathrm{kg}$ wet wt. in Penaeus notialis. The highest average concentration of $90.7 \pm 1.00 \mu \mathrm{g} / \mathrm{kg}$ wet wt. was recorded for Benzo[b]fluoranthene from Bodo City. Between the two species, Callinectes pali accumulated significantly higher concentrations $(P<0.05)$ of total PAHs at all the sites except at Kaa. High molecular weight PAHs (HMW-PAHS) were generally predominant compared to low molecular weight PAHS (LMW-PAHS). The LMW-PAH/HMW-PAH ratios were < 1 for both species, indicating anthropogenic, mainly pyrogenic, origin of PAHs in Kaa, B-Dere and Bodo City of OgoniLand. Concentration of benzo[a]pyrene in Callinectes pali collected from B-Dere and Bodo City analyzed exceeded the EU recommended limit of $2 \mu \mathrm{g} / \mathrm{kg}$ wet wt., while that in Penaeus notialis collected from the three sites were below $E U$ recommended limit of $2 \mu \mathrm{g} / \mathrm{kg}$ wet wt. in food. Thus, PAHs residues in the examined Callinectes pali were high and would constitute threat to human health than those in Penaeus notialis. The public health concerns of $P A H s$ are cancer, mutations and birth defects as discussed.
\end{abstract}

Keywords:Callinectes pali, carcinogenic, OgoniLand, PAHs, Penaeus notialis

Submitted Date 18 June 2013

Accepted Date: 24 June 2013

\section{Introduction}

Polycyclic aromatic hydrocarbons (PAHs) are found in crude oil in significant amounts, with some exceeding $2000 \mu \mathrm{g} / \mathrm{kg}$ [1]. Fish and other aquatic foods are regarded in nutrition as highly desirable food due to its contribution of high quality protein and often low fat. This has attracted consumers due to its health benefits in addition to their widespread and relatively low price. In Nigeria markets, salt water shrimp and crabs are some of the most common aquatic animal types. Thus any high level pollutant detected in these aquatic food exhibits a considerable public health risk [2].

Polycyclic aromatic hydrocarbon (PAHs) is a large group of organic compounds that are included in the European Union and US Environmental Protection Agency (US EPA) priority pollutant list due to their mutagenic and carcinogenic properties [3]. Excluding smokers and occupationally exposed populations, most individuals are exposed to PAHs predominantly from dietary sources [4]. In the marine environment, PAHs are bioavailable to marine species through the food chain, as waterborne compounds and from contaminated sediments. As lipophilic compounds they can easily cross lipid membranes and have the potential to bio accumulate in aquatic organisms. Although for most people, fish and seafood represents only a small part of the total diet, the contribution of this food group to the daily intake of PAHs in some individuals may be comparatively important [5]. With the aim of minimizing harmful effects on human health, recently, the European Union established a maximum level of $2 \mathrm{ng} / \mathrm{g}$ wet weight for benzo[a]pyrene (the marker used for the carcinogenic risk of PAHs in muscle meat of fish [6]. Recently, it was attributed to dibenzo [a, 1] pyrene a carcinogenic potency that is approximately 100 times that of benzo[a]pyrene [7]. Until now, however, works that include the determination of dibenzo [a, 1] pyrene in food are limited [8].

At present, Nigeria depends largely on oil-exploration as the main source of revenue and crude oil is known to contain PAHs at significant levels. This study was designed to investigate the impact of oil spillage on the presence and concentration of PAHs in two species of seafood widely consumed in most communities in Ogoniland, Rivers State, Nigeria and the source of PAHs in these species of seafood. Two species of seafoodwere selected because of their high consumption in the study area.This study will also add to the database for proper assessment and environmental monitoring of oil-derived pollutants in this region. 


\section{Materials and Methods}

\subsection{Study area}

Ogoniland has a tragic history of pollution from oil spills and oil well fires; although no systematic scientific information has been available about the ensuing contamination. Ogoniland is a region covering some $1,000 \mathrm{~km} 2$ in the south-east of the Niger Delta basin (Figure 1). It has a population of close to 832,000, consisting mainly of the Ogoni people.

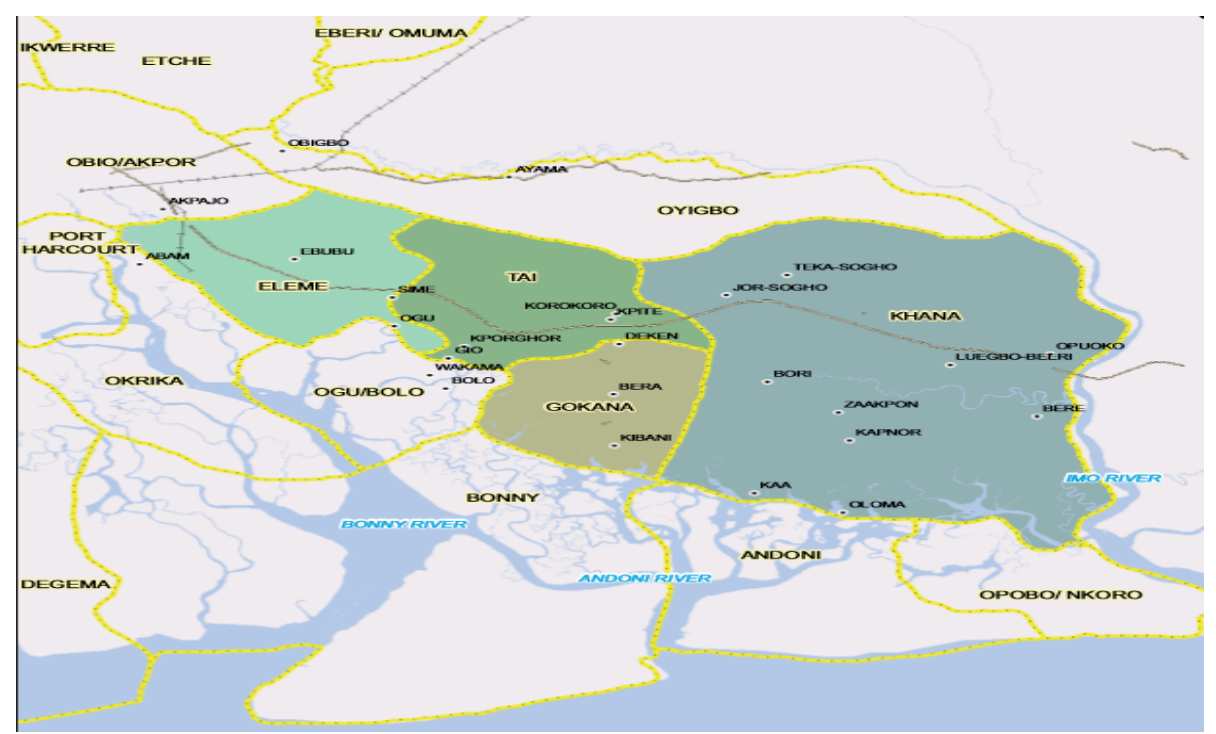

Figure 1.0: Map of Ogoniland showing the two Local Government Areas (LGA) were the study was carried out (Khana and Gokana, LGA).

\subsection{Collection of test samples}

Fresh samples of Callinectes pali and Penaeus notialis were collected from landing beaches of Bodo City, B-Dere and Kaa water side (in Gokana and Khana Local Government Area) respectively, Rivers State, Nigeria. The identities were confirmed by Dr. U. I. Daniel - a Fisheries Expert at the Hydrobiology Unit, Department of Animal and Environmental Biology, University of Port Harcourt, Nigeria. At each site, shrimps and crabs of similar size of each species were collected, cleaned and wrapped in aluminum foils, then kept frozen in an ice chest before transported to the laboratory for analysis.

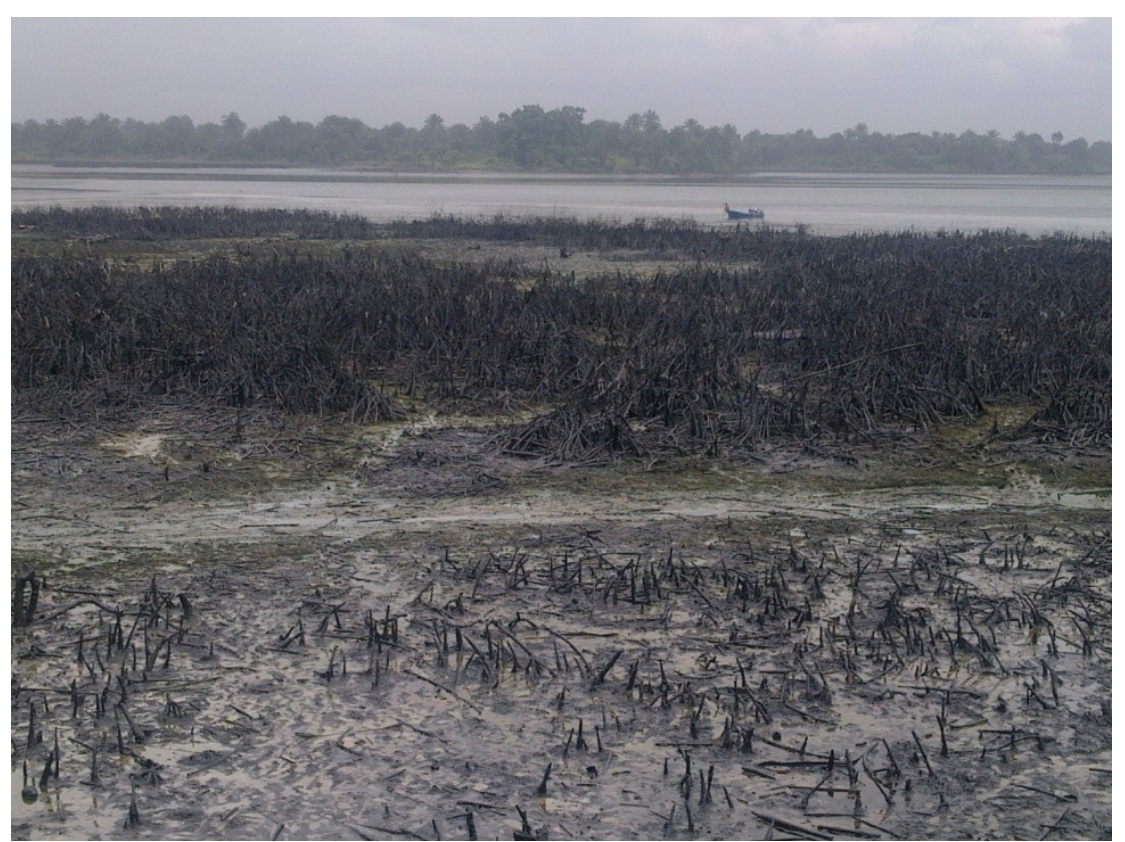

Figure 2: Crude oil polluted water of Bodo City inOgoniland, Rivers State, Nigeria. 


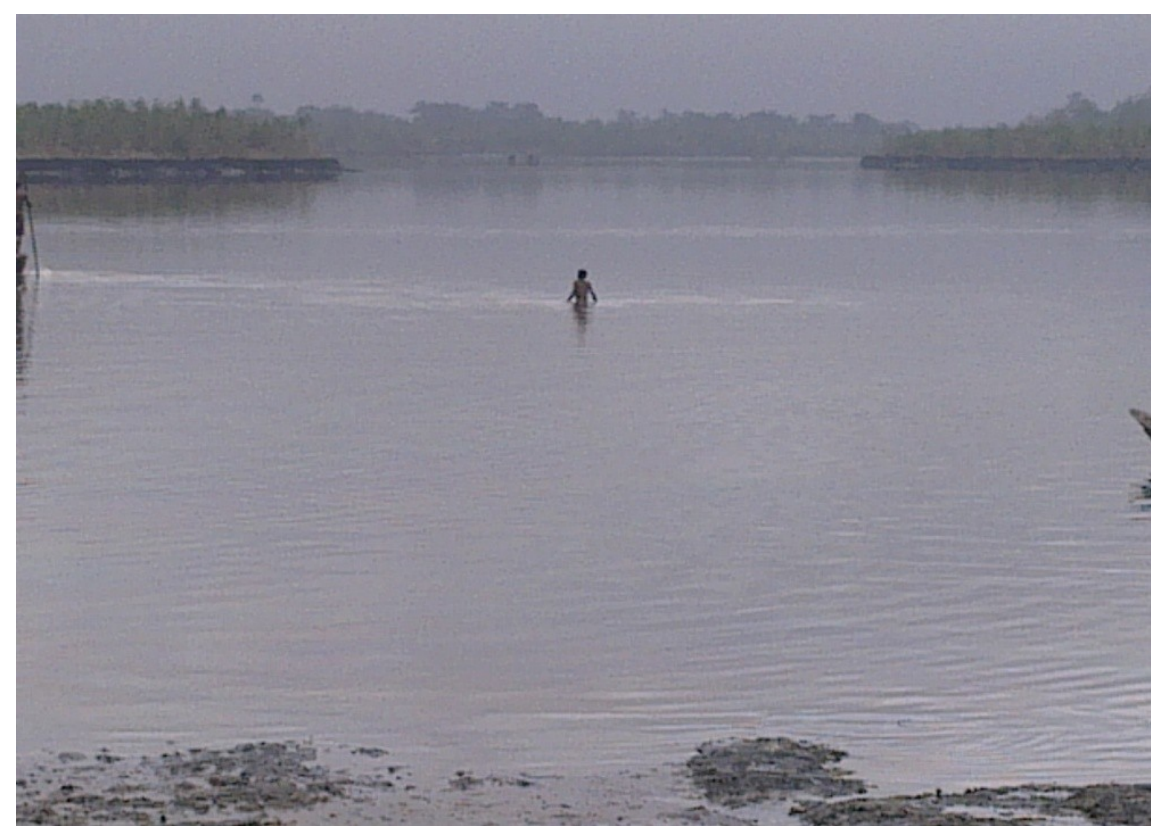

Figure 3: Crude oil polluted water of B-Dere in Ogoniland, Rivers State, Nigeria

\subsection{Reagents}

All reagents used in this study were of analytical grades with high purity.

\subsubsection{Determination of Polycyclic Aromatic Hydrocarbons levels in seafood \\ 2.4.1 Processing of seafood}

The fresh fish samples were dried in the oven for 144h. They were then ground with blender (National, MX 795N, Japan) and kept in air tight containers prior to extraction process.

\subsubsection{Extraction}

Two grams (2g) of sample were weighed into a clean extraction container $(50 \mathrm{ml}$ beaker) and $10 \mathrm{ml}$ of extraction solvent (dichloromethane) was added into the sample and mixed thoroughly and allowed to settle. The sample was carefully filtered into clean solvent rinsed extraction bottle, using filter paper fitted into Buchner funnels. The extract was concentrated to $2 \mathrm{ml}$ and then transferred for cleanup/separation.

\subsubsection{Cleanup/separation}

$1 \mathrm{~cm}$ of moderately packed glass wool was placed at the bottom of $10 \mathrm{~mm} \mathrm{ID} * 250 \mathrm{~mm}$ Loup chromatographic column. Slurry of $2 \mathrm{~g}$ activated silica in $10 \mathrm{ml}$ methylene chloride was prepared and placed into the chromatographic column. To the top of the column was added $0.5 \mathrm{~cm}$ of sodium sulphate. The column was rinsed with additional $10 \mathrm{ml}$ methylene chloride and pre-eluted with $20 \mathrm{ml}$ of dichloromethane. This was allowed to flow through the column at a rate of about 2 minutes until the liquid in the column was just above the sulphate layer. Immediately $1 \mathrm{ml}$ of the extracted samples was transferred into the column. The extraction bottle was rinsed with $1 \mathrm{ml}$ of dichloromethane and added to the column as well. The stop clock of the column was opened and the element was collected with a $10 \mathrm{ml}$ graduated cylinder.

Just prior to exposure of the sodium sulphate layer to air, dichloromethane was added to the column in $1-2$ increments. Accurately measured volume of $8-10 \mathrm{ml}$ of the eluent was collected and labeled.

\subsubsection{Gas Chromatography Analysis}

The concentrated aliphatic fractions were transferred into labeled grass vials with rubber clip cap for gas chromatography analysis. $1 \mu 1$ of the concentrated sample was injected by means of hypodermic syringe through a rubber septum into the column. Separation occurred at the vapor constituent partition between the gas and liquid phase. The sample was automatically detected as it emerges from the column (at constant flow rate) by the FID detector whose response is dependent upon the composition of the vapor.

\subsubsection{Chromatographic conditions}

The gas chromatography was Hewlett Packed 5890 series II, gas chromatography apparatus, coupled with flame ionization detector (FID) (Hewlett Packard, Wilmington, DE, USA), powered with HP chemstation 
Rev. A 09:01 (10206) software to identify and quantify compounds. The GC operating conditions were as specified by the procedural manual.

\subsection{Statistical analysis}

Statistical significance was assessed using a one-way analysis of variance (ANOVA). Comparisons of PAHs levels between species within sites were made using student t-test while one-way analysis of variance (ANOVA) was performed to compare PAHs levels between species across sites with the statistical package SPSS 14.0.2 (SPSS Inc., Chicago, USA).

\section{Results}

Physico-chemical parameters of water samples: The variations in physical and chemical characteristics of the water samples collected from oil spill affected waters (B-Dere and Bodo City) and non- oil spill affected water (Kaa) are shown in Table 1. Temperature varied between $28.0-29.5^{\circ} \mathrm{C}$, while the dissolved oxygen (DO) and pH varied from $2.34-7.80 \mathrm{mg} / \mathrm{L}$ and $6.61-7.30$ respectively and were generally lower in most of the samples collected from oil spill affected waters than the non-oil spill areas. The Total Dissolved Solids (TSS) and Total Suspended Solids (TSS) varied from 9.00- $1589 \mathrm{mg} / \mathrm{L}$ and $1.86-3.30 \mathrm{mg} / \mathrm{L}$ respectively, with the highest values recorded for water collected at Bodo City, while the lowest value recorded for water collected from Kaa for both Total Dissolved Solids (TSS) and Total Suspended Solids (TSS). Chemical Oxygen Demand and Biological Oxygen Demand also varied from $0.19-0.560$ and $0.12-0.63 \mathrm{mg} / \mathrm{L}$ respectively. Highest Oil and Grease was recorded for water collected from B-Dere $(79.1 \mathrm{mg} / \mathrm{L})$, while the lowest Oil and Grease was recorded for water collected from Kaa $(0.01 \mathrm{mg} / \mathrm{L})$.

Tables 1: Physiochemical properties of oil spill polluted waters and non-oil spill polluted water.

\begin{tabular}{lllllllll}
\hline & pH & Temperature & TDS & DO & COD & BOD & TSS & Oil \& Grease \\
\hline & & ${ }^{0} \mathrm{C}$ & $\mathrm{mg} / \mathrm{L}$ & $\mathrm{mg} / \mathrm{L}$ & $\mathrm{mg} / \mathrm{L}$ & $\mathrm{mg} / \mathrm{L}$ & $\mathrm{mg} / \mathrm{L}$ & $\mathrm{mg} / \mathrm{L}$ \\
Kaa(Control) & 7.30 & 29.5 & 9.02 & 7.80 & 0.19 & 0.12 & 1.86 & 0.01 \\
B-Dere & 6.61 & 28.3 & 1576 & 2.34 & 0.38 & 0.28 & 2.40 & 79.11 \\
Bodo City & 6.53 & 29.1 & 1589 & 2.10 & 0.56 & 0.63 & 3.32 & 63.32 \\
\hline
\end{tabular}

Concentration of PAHs:The average PAH concentrations (above mean \pm S.E.M, $\mu \mathrm{g} / \mathrm{kg}$ wet wt.), Total mean PAH concentrations ( $\mu \mathrm{g} / \mathrm{kg}$ wet wt.) and the LMW-PAH/HMW-PAH ratio in Callinectes paliandPenaeus notialis are shown in Table 2 and 3. A total of 16 PAHs were analyzed for in Callinectes paliandPenaeus notialisfrom the three sites. Average concentrations of these PAHs ranged from below detection limit of 0.0001 to $90.7 \pm 1.00 \mu \mathrm{g} / \mathrm{kg}$ wet wt. in Callinectes paliand 0.0001 to $77.5 \pm 1.65 \mu \mathrm{g} / \mathrm{kg}$ wet wt. in Penaeus notialis. The highest average concentration of $13.5 \pm 0.66,35.6 \pm 1.13$ and $90.7 \pm 1.00 \mu \mathrm{g} / \mathrm{kg}$ wet wt.inCallinectes pali and $8.87 \pm 0.01,23.1 \pm 2.77$ and $77.5 \pm 1.65 \mu \mathrm{g} / \mathrm{kg}$ wet wt.in Penaeus notialiswas recorded for Benzo[b]fluoranthene from Kaa, B-Dere and Bodo City respectively. Total PAHs concentrations in Callinectes paliwere 13.7 \pm 0.67 , $50.0 \pm 1.16$ and $104 \pm 1.408$ while that of Penaeus notialiswere $9.00 \pm 0.02,24.4 \pm 2.88$ and $82.6 \pm 1.77 \mu \mathrm{g} / \mathrm{kg}$ wet wt. at Kaa, B-Dere and Bodo City respectively. Between the two fish species, Callinectes pali accumulated significantly higher concentrations $(\mathrm{P}<0.05)$ of total PAHs at all the sites.

Benzo[b]fluoranthene concentrations inCallinectes pali from B-Dere and Bodo City respectively, showed marked elevation when compared with Callinectes pali from Kaa (control). There was no significant difference $(\mathrm{P} \leq 0.05)$ in naphthalene, acenephthylene, anthracene, phenanthrene, fluoranthene, pyrene, benzo[a]anthracene, chrysene, Benzo[k]fluoranthene, indeno[1,2,3-cd]pyrene, dibenz[a,h]anthracene concentrations ofTilapia queneesis from all the sites. Similarly, Benzo[b]fluoranthene levels in Liza falcipinis from B-Dere and Bodo City were much higher than those from Kaa.

LMW-PAH/HMW-PAH ratios in Callinectes pali were 0,004, 0.008 and 0.058 while that of Penaeus notialis were 0.003, 0.028 and 0.031 at Kaa, B-Dere and Bodo City, respectively. The LMW-PAH/HMW-PAH ratios in Kaa City were markedly lower relative to the ratios found in B-Dere and Bodo City in both species. The LMW-PAH/HMW-PAH ratios in Callinectes paliand Penaeus notialis species from all the sites were $<1$.

$\mathrm{BaA} /(\mathrm{BaA}+$ Chry) ratios in Callinectes paliwere $0.96,0.93$ and 0.98 while that of Penaeus notialis were 0.94, 0.86 and 0.88 in Penaeus notialis at Kaa, B-Dere, and Bodo City, respectively. The BaA/(BaA + Chry) ratios at all sites in Callinectes pali and Penaeus notialis were $>0.35$. Benzo[a]pyrene concentrations in Callinectes paliat B-Dere and Bodo City were above the European Union (EU) limit of $2 \mu \mathrm{g} / \mathrm{kg}$ wet wt. except at Kaa while that of Penaeus notialis from all sits were below the European Union (EU) limit of $2 \mu \mathrm{g} / \mathrm{kg}$ wet wt. 
Table 2:PAH concentrations ( $\mu \mathrm{g} / \mathrm{kg}$ wet wt.) inCallinectes pali from the study areas (Kaa, B-Dere and Bodo City).Value are mean \pm S.E.M for three replicates, $(n=3)$.

\begin{tabular}{llll}
\hline PAH COMPOUND & KAA $($ CONTROL $)$ & B-DERE & BODO CITY \\
\hline Naphthalene & $\mathrm{BDL}^{\mathrm{a}}$ & $0.001 \pm 0.00^{\mathrm{a}}$ & $0.23 \pm 0.01^{\mathrm{a}}$ \\
Acenaphthylene & $\mathrm{BDL}^{\mathrm{a}}$ & $0.29 \pm 0.01^{\mathrm{a}}$ & $0.05 \pm 0.00^{\mathrm{a}}$ \\
\hline Acenaphthene & $0.01 \pm 0.00^{\mathrm{a}}$ & $0.004 \pm 0.00^{\mathrm{a}}$ & $2.02 \pm 0.02^{\mathrm{b}}$ \\
Fluorene & $0.02 \pm 0.00^{\mathrm{a}}$ & $0.05 \pm 0.00^{\mathrm{a}}$ & $1.63 \pm 0.07^{\mathrm{b}}$ \\
Anthracene & $0.003 \pm 0.00^{\mathrm{a}}$ & $0.06 \pm 0.00^{\mathrm{a}}$ & $1.58 \pm 0.06^{\mathrm{b}}$ \\
Phenanthrene & $0.01 \pm 0.00^{\mathrm{a}}$ & $\mathrm{BDL}^{\mathrm{a}}$ & $0.26 \pm 0.01^{\mathrm{a}}$ \\
Fluoranthene & $0.01 \pm 0.00^{\mathrm{a}}$ & $0.002 \pm 0.00^{\mathrm{a}}$ & $0.19 \pm 0.01^{\mathrm{a}}$ \\
Pyrene & $0.03 \pm 0.00^{\mathrm{a}}$ & $0.01 \pm 0.00^{\mathrm{a}}$ & $0.38 \pm 0.02^{\mathrm{a}}$ \\
Benz[a]anthracene & $0.02 \pm 0.00^{\mathrm{a}}$ & $0.06 \pm 0.00^{\mathrm{a}}$ & $0.36 \pm 0.02^{\mathrm{a}}$ \\
Chrysene & $\mathrm{BDL}^{\mathrm{a}}$ & $0.004 \pm 0.00^{\mathrm{a}}$ & $0.01 \pm 0.00^{\mathrm{a}}$ \\
Benzo[b]Fluoranthene & $13.5 \pm 0.66^{\mathrm{a}}$ & $35.6 \pm 1.13^{\mathrm{b}}$ & $90.7 \pm 1.00^{\mathrm{c}}$ \\
Benzo[k]Fluoranthene & $0.02 \pm 0.00^{\mathrm{a}}$ & $0.05 \pm 0.00^{\mathrm{a}}$ & $0.01 \pm 0.00^{\mathrm{a}}$ \\
Benzo[a]Pyrene & $0.001 \pm 0.00^{\mathrm{a}}$ & $2.01 \pm 0.00^{\mathrm{b}}$ & $2.82 \pm 0.01^{\mathrm{b}}$ \\
Indenol[1,2,3-cd]Pyrene & $0.06 \pm 0.00^{\mathrm{a}}$ & $11.8 \pm 0.00^{\mathrm{b}}$ & $4.18 \pm 0.17^{\mathrm{c}}$ \\
Dibenz[a, h]anthracene & $0.004 \pm 0.00^{\mathrm{a}}$ & $0.01 \pm 0.00^{\mathrm{a}}$ & $0.03 \pm 0.01^{\mathrm{a}}$ \\
Benzo[g, h,1]perylene & $0.001 \pm 0.00^{\mathrm{a}}$ & $0.03 \pm 0.00^{\mathrm{a}}$ & $0.04 \pm 0.00^{\mathrm{a}}$ \\
Total PAHs & $13.7 \pm 0.67^{\mathrm{a}}$ & $50.0 \pm 1.16^{\mathrm{b}}$ & $104 \pm 1.41^{\mathrm{c}}$ \\
LMW-PAH/HMW-PAH ratio & 0.004 & 0.008 & 0.058 \\
BaA/(BaA + Chry) ratio & 0.96 & 0.93 & 0.98 \\
\hline
\end{tabular}

Values with different superscript letters $(a, b, c)$ in the same column are significantly different at the 0.05 level ( $\mathrm{P} \leq 0.05)$. BDL implies below detection limits of $0.0001 \mu \mathrm{g} / \mathrm{kg}$ wet wt.).

Table 3:PAH concentrations ( $\mu \mathrm{g} / \mathrm{kg}$ wet wt.) in Penaeus notialis from the study areas (Kaa, B-Dere and Bodo

\begin{tabular}{|c|c|c|c|}
\hline PAH COMP0UND & KAA (CONTROL) & B-DERE & BODO CITY \\
\hline Naphthalene & $\mathrm{BDL}^{\mathrm{a}}$ & $0.004 \pm 0.00^{\mathrm{a}}$ & $\mathrm{BDL}^{\mathrm{a}}$ \\
\hline Acenaphthylene & $\mathrm{BDL}^{\mathrm{a}}$ & $0.01 \pm 0.00^{\mathrm{a}}$ & $\mathrm{BDL}^{\mathrm{a}}$ \\
\hline Acenaphthene & $0.01 \pm 0.00^{\mathrm{a}}$ & $0.229 \pm 0.03^{\mathrm{a}}$ & $0.64 \pm 0.01^{\mathrm{a}}$ \\
\hline Fluorene & $0.01 \pm 0.00^{\mathrm{a}}$ & $0.27 \pm 0.00^{\mathrm{a}}$ & $0.52 \pm 0.01^{\mathrm{a}}$ \\
\hline Anthracene & $\mathrm{BDL}^{\mathrm{a}}$ & $0.15 \pm 0.02^{\mathrm{a}}$ & $0.26 \pm 0.01^{\mathrm{a}}$ \\
\hline Phenanthrene & $0.01 \pm 0.01^{\mathrm{a}}$ & $0.01 \pm 0.00^{\mathrm{a}}$ & $1.09 \pm 0.02^{b}$ \\
\hline Fluoranthene & $0.01 \pm 0.00^{\mathrm{a}}$ & $0.01 \pm 0.00^{\mathrm{a}}$ & $0.33 \pm 0.01^{\mathrm{a}}$ \\
\hline Pyrene & $0.02 \pm 0.00^{\mathrm{a}}$ & $0.003 \pm 0.00^{\mathrm{a}}$ & $0.13 \pm 0.00^{\mathrm{a}}$ \\
\hline Benz[a]anthracene & $0.02 \pm 0.00^{\mathrm{a}}$ & $0.03 \pm 0.00^{\mathrm{a}}$ & $0.13 \pm 0.00^{\mathrm{a}}$ \\
\hline Chrysene & $0.001 \pm 0.00^{\mathrm{a}}$ & $0.004 \pm 0.00^{\mathrm{a}}$ & $0.02 \pm 0.00^{\mathrm{a}}$ \\
\hline Benzo[b]Fluoranthene & $8.87 \pm 0.01^{\mathrm{a}}$ & $23.1 \pm 2.77^{\mathrm{b}}$ & $77.5 \pm 1.65^{c}$ \\
\hline Benzo[k]Fluoranthene & $0.01 \pm 0.00^{\mathrm{a}}$ & $\mathrm{BDL}^{\mathrm{a}}$ & $0.01 \pm 0.00^{\mathrm{a}}$ \\
\hline Benzo[a]Pyrene & $0.001 \pm 0.00^{\mathrm{a}}$ & $0.001 \pm 0.00^{\mathrm{a}}$ & $0.002 \pm 0.00^{\mathrm{a}}$ \\
\hline Indenol [1,2,3-cd]Pyrene & $0.04 \pm 0.00^{\mathrm{a}}$ & $0.51 \pm 0.06^{\mathrm{a}}$ & $1.96 \pm 0.05^{b}$ \\
\hline Dibenz $[\mathrm{a}, \mathrm{h}]$ anthracene & $0.003 \pm 0.00^{\mathrm{a}}$ & $0.002 \pm 0.00^{\mathrm{a}}$ & $0.01 \pm 0.00^{\mathrm{a}}$ \\
\hline Benzo[g, h,1]perylene & $0.001 \pm 0.00^{\mathrm{a}}$ & $\mathrm{BDL}^{\mathrm{a}}$ & $0.01 \pm 0.00^{\mathrm{a}}$ \\
\hline Total PAHs & $9.00 \pm 0.02^{\mathrm{a}}$ & $24.4 \pm 2.88^{b}$ & $82.6 \pm 1.77^{\mathrm{c}}$ \\
\hline LMW-PAH/HMW-PAH ratio & 0.003 & 0.028 & 0.031 \\
\hline $\mathrm{BaA} /(\mathrm{BaA}+$ Chry $)$ ratio & 0.94 & 0.86 & 0.88 \\
\hline
\end{tabular}

Values with different superscript letters $(a, b, c)$ in the same column are significantly different at the 0.05 level $(\mathrm{P} \leq 0.05)$. BDL implies below detection limits of $0.0001 \mu \mathrm{g} / \mathrm{kg}$ wet wt.).

\section{Discussion}

Physiochemical parameters of waters: The mean $\mathrm{pH}$ values for the polluted samples were 6.53 and 6.61 compared to values 7.30 obtained for the control sample. It can be deduced from this result that variety of contaminations may be attributed to oil spill of petroleum products in the vicinity of the water. These may include acidic gases which in solution slightly increased the acidity of both surface and ground water. The obtained $\mathrm{pH}$ values for both B-Dere and Bodo City water were generally lower than the $\mathrm{pH}$ values obtained for the control sample from Kaa which revealed a likely alteration in the natural chemistry of the environment within the water as a result of the oil activities. The $\mathrm{pH}$ of water sample from B-Dere and Bodo City was found to be slightly acidic and below that of the control sites. 
The best temperature for shell fish depends on the species, but in general tropical fish are most healthy in the range of $75-80^{\circ} \mathrm{F}\left(24-27^{\circ} \mathrm{C}\right)$. Cold water fish do better in temperatures well below that, some of them enjoy water well below $70^{\circ} \mathrm{F}$, which is not suitable for any tropical fish [9]. In this study, the temperature were 29.5, 28.3 and $29.1^{\circ} \mathrm{C}$ for Kaa, B-Dere and Bodo City respectively, which to some extent may not have adverse effect on the seafoodcaught from the three sites. Chemical Oxygen Demand (COD) measured the amount of material that can be oxidized (combined with oxygen) in the presence of a strong chemical oxidizing agent. Since the COD test can be performed rapidly, it is often used as a rough approximation of the water's BOD, even though the COD test measures some additional organic matter (such as cellulose) which is not normally oxidized by biological action. As with the BOD test, the COD test is reported as $\mathrm{mg} / \mathrm{L}$ of oxygen used [9]. The concentrationsof BOD were 0.38 and $0.56 \mathrm{mg} / \mathrm{L}$ for B-Dere and Bodo City respectively while that of control was $0.19 \mathrm{mg} / \mathrm{L}$. Biological Oxygen Demand (BOD) values for the polluted samples were 0.28 and $0.63 \mathrm{mg} / \mathrm{L}$ compared to values $0.12 \mathrm{mg} / \mathrm{L}$ obtained for the control sample water which were within permissible level. Water having a BOD of less than $1 \mathrm{mg} / \mathrm{l}$ can be relatively unimpacted by humans and primary candidates for conservation. Therefore, BOD standards are set at $2-3 \mathrm{mg} / \mathrm{L}$, respectively.

Measured Total Suspended Solid (TSS) was 2.4 and $3.3 \mathrm{mg} / \mathrm{L}$ from B-Dere and Bodo City which was significantly lower compared to the standard of TSS which was 1.86 . Generally measured TSS should be less than $25 \mathrm{mg} / \mathrm{L}$ to prevent any harmful effect to the aquatic environments [9]. TSS concentration of more than 50 $\mathrm{mg} / \mathrm{l}$ affect the proper functioning of shellfish's. Total Suspended Solid standards of $50 \mathrm{mg} / \mathrm{l}$ and $25 \mathrm{mg} / \mathrm{L}$ have been adopted for fisheries and water supply use respectively[9]. Previous author have reported a direct correlation between the PAHs and total suspended solids because PAHs (most especially higher molecular ones) are capable of attaching to particles of dissolved solids and only a small amount of the total load of the chemicals was found in dissolved form [9].

The principal application of TDS is in the study of water quality for streams rivers and lakes, although TDS is not generally considered a primary pollutant (e.g. it is not deemed to be associated with health effects) it is used as an indication of aesthetic characteristics of drinking water and as an aggregate indicator of the presence of a broad array of chemical contaminants. More exotic and harmful elements of TDS are pesticides arising from surface runoff. Certain naturally occurring total dissolved solids arise from the weathering and dissolution of rocks and soils. The United States has established a secondary water quality standard of $500 \mathrm{mg} / \mathrm{l}$ to provide for palatability of drinking water but from the study TDS from B-Dere and Bodo City were 1576 and $1589 \mathrm{mg} / \mathrm{L}$ respectively which is three times above the normal range for most country, while that of Kaa water was just $9.02 \mathrm{mg} / \mathrm{L}$.

Dissolved oxygen (DO) levels in natural and wastewaters depend on the physical, chemical, and biochemical activities in the water body. The analysis for DO is a key test in water pollution and waste treatment process control[9]. It was observed that Dissolved Oxygen of river from Kaa was 7.80 as compared with B-Dere and Bodo City which was 2.34 and 2.10, respectively. This may be associated with the massive death of aquatic life found at the oil spill affected sites (B-Dere and Bodo City. The Dissolved Oxygen (DO) standards have been formulated, considering fisheries criteria. Relatively good water bodies have more than $7.50 \mathrm{mg} / \mathrm{l}$. For fisheries, more than $7.00 \mathrm{mg} / \mathrm{l} \mathrm{DO}$ is required[9]. It therefore follows that DO from B-Dere and Bodo City is below required for aquatic organism to thrive. Other general aquatic organisms also require more than $6 \mathrm{mg} / \mathrm{l}$. In Ohio State, USA, the DO standard for fisheries is $5 \mathrm{mg} /[$ [9]. The DO Level for the conservation of the environment should be kept at more than $2 \mathrm{mg} / \mathrm{l}$ to prevent anaerobic conditions that cause bad odors[9]. The results of the oil and grease $(\mathrm{mg} / \mathrm{l})$ for both B-Dere and Bodo City water samples are presented in table 1.The results indicated high oil and grease contents in the surface water which ranged between 79.1 and 62.3 $\mathrm{mg} / \mathrm{L}$. The control sites for the surface water showed a low content of oil and greases values of $0.01 \mathrm{mg} / \mathrm{L}$. The results indicate a high contamination of surface water by petroleum products within the vicinity of B-Dere and Bodo City. A statistically significant difference ( 0.05 levels) existed for the concentrations of oil and grease in the surface water samples in comparison with those of the control sites - Kaa. This is an indication of contamination of the surface water by petroleum products. These contaminations may not be far from the fact that all effluents from oil prospecting company's, oil spillage, pipeline bursts and other cleaning activities that take place in the areas are channeled to outlet along the course of this stream. The observed high oil and grease content in the surface water may also be associated with industrial and commercial cleaning activities.

PAHs distribution and concentration: Exposure pathways of Polycyclic Aromatic Hydrocarbons (PAHs) to fish include bio concentration from water across their gills and skin [10] and ingestion of PAHcontaminated particulate matter along with food [11]. PAHs readily adsorb onto particulate organic matterespecially soil sediments[12,13]. PAHs are lipophilic and so they accumulate in the fatty tissues of fish following their uptake [14]. Callinectes pali feed on detritus organic particles, Penaeus notialis are omnivorous, feeding on marine worms, crustaceans, large planktonic organisms, sponges, dead animals and plant materials $[15,16]$. These may be the reasons why some of this fish species have a significant higher $(\mathrm{P}<0.05)$ concentration of PAHs. 
According to United Nation Environmental Protection agency report on Environmental Assessment of OgoniLand [17].Concentrations of 16 PAHs in fish, oysters and mussels from the four Ogoni Local Government Areas which included two of the LGAs (Khana and Gokana) were this research work was carried out reported that PAHs were low in all samples. It also reported that fresh fish and seafood concentrations were below the detection limit for most of the different PAHs and in a few cases, measurable but low levels were found [17].

It is important to note that this present study is at variance with the report (UNEP report on Ogoniland) as the PAH levels obtained in most part fell above the specification for PAH in foods. The populations living within the study areas areat great risk of having cancer and other serious ailments. At B-Dere, Penaeus notialis accumulated significantly lower $(\mathrm{P}<0.05)$ concentrations of total PAHs compared toCallinectes pali. This is possibly due to local physical mixing, which can result in re- suspension of bottom sediments and redistribution of PAHs into the water column [18], thereby, exposing both fishes to PAHs irrespective of where these fishes may be found. The observed differences in PAH bioaccumulation in both species may also be attributed to differences in feeding preferences and general behavior [19], as well as the mode of feeding in these species [20]. The LMW- PAH/HMW-PAH ratios indicate that the HMW-PAHs were generally predominant compared to the LMW-PAHs. The predominance of HMW-PAHs may be due to the fact that LMW-PAHs are preferentially degraded during PAH transport and burial into sediments [21].

The levels of concentrations of Polycyclic Aromatic Hydrocarbons in fish, shrimp and crab reflect the state of contamination of the environment [22] and, therefore, the observed levels of total PAHs in seafood in this study indicate high levels of PAH contamination at B-Dere and Bodo City relative to Kaa (control). The LMW-PAH/HMW-PAH ratios observed in both species from all the three sites were $<1$, indicating that the sources of these PAHs in the fish analyzed are mainly pyrogenic [23], and are a clear indication of anthropogenic pollution of PAHs in the coastal marine environment.

The observed $\mathrm{BaA} /(\mathrm{BaA}+\mathrm{Chry})$ ratios in both species from all the sites were $>0.35$, this also indicated pyrogenic source of PAHs contamination. Possible anthropogenic sources include combustion of petroleum, automobile tire, and wood and vehicle emission. PAHs may then be transported from their points of release to the coastal environment via surface runoff and atmospheric deposition [24]. PAHs are known to cause growth reduction [25], endocrine alteration [11], malformations of embryo and larvae [26, 27] and DNA damage [28]in fish, as well as human health effects such as cancer, mutations and birth defects [29, 30]. They may also have adverse impacts on marine life[31].

\section{Conclusion}

This study established the fact that Polycyclic Aromatic Hydrocarbons levels detected in Callinectes paliand Penaeus notialis are high and, thus, consumption of these fishes may pose significant health risk to the populace who consume this fish species. The results also suggest that fishes from Kaa area are safer for consumption compared to species found in B-Dere and Bodo City. Contrary to UNEP report that fish consumption from Gokana and Khana Local Government Areas (LGA) are safe for consumption, this study shows that they may not be safe for consumption.

\section{References}

[1]. A.Moret, S., Dudine, andL.S Conte (2000). J. Am. Oil Chem. Soc. 77,2000, 1289-1292.a

[2]. T.V. Cirillo,E. Viscardi,A. Fasano,R. Farinaand Amodio-Cocchieri. Polychlorinated biphenyls, organochlorine pesticides and polycyclic aromatic hydrocarbons in wild, farmed and frozen marine seafood marketed in Campania, Italy. Journal of Food Protection, 72(8), 2009, 1677-1685.

[3]. USEPA, Guidance for Assessing Chemical Contaminant Data for Use in Fish Advisories, EPA/823/B-00/007, United States Environmental Protection Agency, 2000.

[4]. L.R. Bordajandi, M. Dabrio, F. Ulberth, H. Emons. J. Sep. Sci. 31, 20081769-1778.

[5]. J. L. Domingo. Contributions to Science, 3, 2007, 459-468.

[6]. European Union, Commission Regulation (EC) No 208/2005, Off. J. Eur. Comm. L34, 2005, 3-5.

[7]. K.B. Okona-Mensah, J. Battershill, A. Boobis, R. Fielder. Food Chem. Toxicol. 43, 2005, $1103-1116$

[8]. L. Duedahl-Olesen, F. Ghorbani. Polycycl. Aromat. Compd. 28, 2008, 282-301.

[9]. APHA Standard methods for examination of water and waste water; American Public health Association, Washington, DC, (1998)

[10]. F.A.P.C. Gobas, J.B. Wilcockson, R.W. Russell and G.D. Haffner. Mechanism of biomagnification in fish under laboratory and field conditions, Envir. Sci. Technol, 33, 1999, 133-141.

[11]. J.P. Meador, F.C. Sommers, G.M. Ylitalo andC.A. Sloan. Altered growth and related physiological responses in juvenile Chinook salmon (Oncorhynchus tshawytscha) from dietary exposure to polycyclic aromatic hydrocarbons (PAHs). Can. J. Fish. Aquat. Sci. $63,2006,2364-2376$.

[12]. S.W. Fowler and G.A. Knauer, G. A. Role of large particles in the transport of elements and organic compounds through the oceanic water column. Prog. Oceanog. 16, 1986, 147-194.

[13]. C. Raoux, J.M. Bayona, J.C. Miquel, J.L. Teyssie, S.W. Fowler and J. Labaiés. Particulate fluxes of aliphatic and aromatic hydrocarbons in near shore waters to the north-western Mediterranean Sea, and the effect of continental runoff. Estuar. Coast. Shelf Sci. 48, 1999, 605-616.

[14]. I. Bouloubassi, J. Fillaux, J. and A. Saliot. Hydrocarbons in surface sediments from Changjian (Yangtze River) estuary, East China Sea. Mar. Pollut. Bull. 42, 2001, 1335-13462.

[15]. W. Schnieder. Field Guide to the commercial marine resources of the Golf of Guinea, FAO, Rome, 1990. 
[16]. [16] F.D. Sikoki and A. Francis. An atlas of fin fishes of the Andoni Riverin Niger Delta, Nigeria. Molsytem United Services, Elder Johnson Worlu close Port Harcourt, 68p, 2007.

[17]. UNEP (2011). United Nation Environmental Protection report on OgoniLand, 181p

[18]. E. Jurado, J.M. Zaldívar, D. Marino and J. Dachs. Fate of persistent organic pollutants in the water column: does turbulent mixing matter? Mar. Pollut. Bull. 54, 2007, 441-451.

[19]. S.W. Fisher. Mechanisms of bioaccumulation in aquatic systems. Rev. Envir. Contamin. toxicol. 142, 1995, 87-118.

[20]. K.Y. Kong, K.C. Cheung, C.K.C. Wong and M.H. Wong. The residual dynamic of polycyclic aromatic hydrocarbons and organochlorine pesticides in fishponds of the Pearl River delta, South China. Wat. Res. 39, 2005, 1831-1843.

[21]. D. Berto, F. Cacciatore, A. Ausili, G. Sunseri, G. Luca, L.G. Bellucci, M. Frignani, S. Albertazzi and M. Giani. Polycyclic Aromatic Hydrocarbons (PAHs) from Diffuse Sources in Coastal Sediments of a Not Industrialised Mediterranean Island. Wat. Air Soil Pollut. 200, 2009, 199-209.

[22]. A.L. Lanfranchi, M.L. Menone, K.S.B. Miglioranza, L.J. Janiot, J.E. Aizpu andV.J. Moreno. Striped weakfish (Cynoscion guatucupa): a biomonitor of organo chlorine pesticides in estuarine and near-coastal zones. Mar. Pollut. Bull. 52, 2006 74-80.

[23]. V. Rocher, S. Azimi, R. Moilleron and G. Chebbo. Hydrocarbons and heavy metals in the different sewer deposits in the "Le Marais" catchment (Paris, France): Stocks, distributions and origins. Sci. Total Environ. 2004:323:107-122.

[24]. E. Lipiatou and A. Saliot. Fluxes and transport of anthropogenic and natural polycyclic aromatic hydrocarbons in the western Mediterranean Sea. Mar. Chem. 32, 1991, 51-75.

[25]. J.S. Christiansen and S.G. George. Contamination of food by crude oil affects food selection and growth performance, but not appetite, in an Arctic fish, the polar cod (Boreogadus saida). Polar Biol. 15, 1995, 277-281.

[26]. M.G. Carls, L. Holland, M. Larsen, T.K. Collier, N.L. Scholz and J.P. Incardona,(2008). Fish embryos are damaged by dissolved PAHs, not oilParticles. Aquat. Toxicol. 88, 121-127.

[27]. L. Camus andG.H. Olsen. Embryo a b e r r a t i o n s i n s e a i c e a m p h i p od (Gammaruswilkitzkii) exposed to water soluble fraction of oil. Mar. Envir. Res. 66, 2008, 221-222.

[28]. I. Caliani, S.Porcelloni, G. Mori, G. Frenzilli, M. Ferraro, L. Marsili, S. Casini and M.C. Fossi. Genotoxic effects of produced waters in mosquito fish (Gambusia affinis). Ecotoxicology 18, 2009, 75-80.

[29]. [29] M.S. Zedec. Polycyclic aromatic hydrocarbons: a review. J. Envir. . Toxicol. 3, 1980, 537-567

[30]. K.L. White. An overview of immunotoxicology and carcinogenic polycyclic aromatic hydrocarbons. Envir. Carcinology Rev. 2, 1986, 163-202.

[31]. E. Nyarko, B.O. Botwe and E. Klubi. Polycyclic Aromatic Hydrocarbon (PAHs) Levels in Two Commercially Important Fish Species from the Coastal Waters of Ghana and their Carcinogenic Health Risks, West African Journal of Applied Ecology, vol. 19, 2011. 